\title{
Changing Nature of Power and Leadership: How do They Matter in Rural Nepal?
}

Mahendra Sapkota

\begin{abstract}
Globally, power and leadership are considered as two unavoidable factors of social change and local development. In Nepal's federal context, the nexus of power and leadership has been less addressed in academic research though most of the studies are focused on local governance. The present study attempts to analyze the nature of leadership and its power structure in the context of rural Nepal. It follows a critical ontological position of the development of power and leadership. Methodologically, a complete leadership of Dogana village in Suddhodhan Rural Municipality of Rupandehi district (Lumbini Province) was undertaken to assess the rural leadership. It is found that the most important factor for holding the rural leadership was 'affiliation with the political party', which was followed by 'well-being ranking' and 'caste/ ethnic status' of the leadership. The rural leaders used to change their policies and strategies to create and sustain power, such as doing multiple professions and building networks other than politics. The paper, therefore, concludes that a significant change occurred in leadership pattern and power structure of rural Nepal from informal to formal, and less inclusive to more inclusive and representative. Despite this, the changes are still elite-centric, politically vested, and economically favorable either to the upper-class people or middle-class mediators (bichauliyas). The study predicts that the contestations in leadership and power-sharing could be more critical in the days to come with the implementation of federalism in the rural context. The implication of this study largely relies on the context of local power structure and village politics in Nepal.
\end{abstract}

Keywords: leadership; Nepal; power relation, rural

\section{The Study Context}

Power and leadership are two prominent issues in contemporary social science as they have been mutually intertwined to affect the pace of socio-economic and political changes. Most of the scholars confirm that leadership cannot exist without power (Jones \& York, 2016). However, the nexus of power and leadership, sometimes reflected as social movements, is not linear and monolithic. It seems to be interconnected in a varied way particularly in the modernization process of the Global South (Geiser, 2014; Martnis, 2018) and of Nepal (Bista, 1991/ 2008; Regmi, 2002). Nepal has possessed several subsequent contradictions in different political regimes since the beginning of the modern history of Nepal in 1768. Yet, leadership studies are less engaged with the rapidly changing power structure in rural contexts. A remarkable change occurred in the power structure of rural Nepal during the last two decades, more specifically during Maoist's insurgency (1996-2006) and after the People's Movement 2006 (Lawoti \& Pahari, 2010); yet many questions upon these movements and changes are still debated. This is further delineated along with the promulgation of a new constitution along with a federal republic system in the country in 2015 (Constitution of Nepal, 2015). The constitution has provisioned 3 tiers of government: federal, provincial, and local (Part 5, Art. 56). All these governments got elected in 2017 and thus 753 local levels have been set with new leadership.

A sociological understanding of local political processes and the local power structure is a relatively less engaged research issue in Nepal's academia and Universities (Mishra, 2011). A particular gap in this regard is the interplay of political dynamics at the local level and its interaction with the State actors and with the non-State actors too (Pradhan, 2011; Sapkota, 2017). However, there is an important reason why a study of the changing rural power structure promises to be particularly illuminating towards an understanding of political change at the local level. Understanding the potential of the rural power structure is a key analytical, and indeed political, imperative towards the modernization of Nepali society. In this context, the present study attempts to assess the nature of changes that occurred in the leadership pattern of rural power structure in Nepal. A complete leadership of Dogana village in Suddhodhan Rural Municipality of Rupandehi district was undertaken as a methodological universe to analyze the different patterns of power changes and dynamics. 


\section{Global Debates and Issues}

The concept of power is a contested notion though it has a central one within the social science literature (Thiele, 2019) - though it is thought to be dominant in western philosophy of political science (Nabers, 2016). The eastern (particularly the Hindu) viewpoint of power and leadership is institutionalized many centuries ago, which closely relates with the concept of people's kalyan (welfare), raj dharma (duty of the king/ ruler), and the legitimacy of the rajya (state) itself (Prabhu, 2019). More recently, a work on power by social theorists has broadened the discussions from political science to sociology, economics, and more recently in development studies. A. Gramsci's (1891-1937) ideas about power emphasized its influence as a totalizing force in favor of the ruling class/ culture what he calls 'hegemony'. The hegemony allows domination of the state over the society through a pervasive institutional power, thereby repressing citizens who may hold alternative or contradictory opinions about state actions (Mozumdar, et al., 2008) and that may challenge the dominant worldview. This is a neo-Marxist perspective of power which assumes binary features of the power, i.e. dialectics of domination and resistance (Gramsci, 2009). Meanwhile, though not discussed explicitly till the 1970s, the discourse of power led some researchers to focus on social movements and other forms of collective action/ behavior and resistance initially in Europe and then in the Latin American and Asian countries. The movement theorists, however, are divided in viewing power in terms of its nature, ideology, strategy, networks, and framing of the movement.

M. Foucault (1926-1984) is another influential critical theorist, who, contrary to the binary construction of power, argues that power is multidimensional often reflected strategically in the contestation of knowledge and power. As such, power is a discourse not simply embedded in structural relations, but is also constituted through language and everyday practices and social controls (Foucault, 1982). This latter idea has also been elaborated by P. Bourdieu (1930-2002), who has also emphasized the importance of 'symbolic power' which is transferred diversely in social orders of generations to generations. He has contributed to understanding the subject within objective structures of social positioning (habitus) - a continuum of structure and agency (Bourdieu, 1977, 1984).

Elite theory is another related connotation of power, which often believes power as a game of 'power elites' of the society. ${ }^{1}$ Contrary to the class analysis of social change and power relations, the term denotes the people (in minority) at the top of the major institutional hierarchies of a society, whose shared interests lead them to form an emergent alliance in making and/or influencing major decisions based on economic, political and social

1. See Vilfredo Pareto (1848-1923), Gaetano Mosca (18581941), and Robert Michels (1876-1936), who are considered as cofounders of the Italian/ European school of elitism. For American tradition of elite theory, see Elmer Eric Schattschneider (1892 -1971) and Charles Wright Mills (1916-1962). relationships. This happens as such irrespective of the rule of law or the democratic mandate of the subjects in the majority, i.e. people. In particular, Mills calls attention to the interwoven interests of the leaders of the dominant positions of military, corporate and political hierarchies of society, and suggests that the ordinary citizens are relatively powerless subject of manipulation by those entities (Mills, 1956/2000).

Power and leadership are mutually interlinked connotations, and many researchers and scholars have outlined the interconnectivity. Scholars have long been interested in leadership throughout human history, but it has only been relatively recently that formal leadership theories have emerged in social sciences. Existing approaches within leadership studies often share a bias towards industrialized societies and lack broader cross-cultural and ethological reference (Garfield, Rueden, \& Hagen, 2018). Historically it is evident that the early leadership theories focused on the qualities of leaders and followers, while modern theories often look at other variables such as situational factors and skill levels. These assertions have been reflected through a variety of theoretical dimensions, including eight major types (Frohlich, \& Oppenheimer, 2015): "Great Man" theories; trait theories; contingency theories; situational theories; behavioral theories; participative theories; management theories; and relationship theories. Indeed, these western theories of leadership are provisional and seem to be comparatively new ones that described the material objective of the state and politics. Ontologically, they are based on the material interpretation of power and leadership.

In contrast to this, the eastern approach of leadership is based on the subjective well-being of all the creatures (not only of the humankind) where the emancipation (expressed as mokshya, nrivarna, and mukti) state is treated just as means to facilitate the service. In the ancient Hindu societies like in Nepal and India, Guru and Acharya were provisioned as the leader and tutors of all these affairs related to emancipation from both the inner and outer world and journey from the darkness to the brightness. It is evident that the Gurus were kept even above the hierarchy of the King and were honored as equivalent to all the God almighty (Bramha, Bishnu, and Mahesh) and the ultimate reality (para-bramha) ${ }^{2}$. However, this system doesn't exist in most of the contemporary societies in this region, and instead, the concepts and practices of political leadership and civil society leadership have been introduced. These approaches are more influenced by the western value of the modern state system.

In theory, the idea of leadership is contested as it cannot be defined as an exact science. Empirically, however, leadership is often asserted with the idea of power, merit, supremacy, and benevolence. There are several characteristics for leadership such as Charisma, inspiration, intellectual stimulation, and individualized consideration (CIMA, 2001). In recent years, political morality has

2 गुरु ब्रह्मा, गुरु विष्णु गुरु देवो महेश्वर, गुरु साक्षात् परमं ब्रह्मा तस्मै श्री गुरुवे नम: 
closely knotted with the idea of leadership. Morality has become a constant political problem associated with leadership and power. Though the morality and ethics of leadership are abstract ideas the morality politics generally is a less prioritized research agenda. Its further connotation is built with the judgment and well-being of the people. In this regard, it is worthwhile to mention Thompson (2019) who defines political morality as "the practice of making moral judgments about political action, and the study of that practice" (p. 1). The morality of leadership cannot be separated from ethics. As argued by Girardin (2012), "ethics in politics is possible - and it pays off" (p. 10), though the ethics and morality of leadership are socially constructed and evolved.

\section{Research Gaps in Nepali Context}

Nepal is a country with a diverse social structure comprising 125 caste/ ethnic groups and 125 lingual groups, though there is a dominance of Hindus $(81.3 \%)$ by religion (CBS, 2012). Most of the geographic and social characteristics belong to the rural area though the country has recently restructured without any particular rural area politically. Rather, there are 460 rural municipalities and other municipal urban areas out of the total of 753 local units in the country. The historical analysis of the pattern of leadership in rural Nepal informs us that no single variable is responsible for the construction of the leaders and their holding of power in rural areas. Member of a strong lineage or descent group, control over agricultural land, right over human power, technological skills, demographic strength constitute a general background of the leader. In rural Nepal, early studies (e.g. Regmi, 1979; Seddon \& Hussein, 2002; Whelfton, 2005) revealed the position of leaders who were particularly inclined to the mainstream politics or the administration adhered by the central state through Kathmandu. This happened throughout the Rana regime (1846-1951) which then also followed in the Panchayat era (1961-1990). Till the 1980s, there was a traditional pattern of leadership in the whole country. During that time, early settlers in the village area grasped political power and social status through the proximity of local Hindu jamindars as revenue collectors.

The research literature on Nepal normally refers to the local power structure as the configuration of the local elite, their networks and resources, and links with both formal institutions (such as local government structures) and informal institutions (such as indigenous social control systems and traditions of patron-clientelism). Regmi (1978) argued that the primary economic strength and social status of local leaders depended on the extent of land ownership. However, level of education was also an important asset for attaining leadership and education had a direct correlation with land ownership patterns. Such leaders have close links with the administration and non-agricultural sources of income. Control over land, linkage with administration, and non-agricultural sources of income are three important variables to get access to the rural power structure. Sapkota (2017) presented village fieldwork data from Dang and Sunsari that the importance of land as the main factor of production - and, therefore, as an index of rural power-was beginning to decline. So, keeping the above view in mind the present study was undertaken to indicate the process of change in the leadership pattern and to identify the nature of the changing categories of leadership in the rural power structure.

Some recent studies in Nepal are more inclined to the federal context and leadership. Though few of such studies are politically positioned either in favor of federalism or against it. It is realized that the federal system has evolved contested issues in terms of power and leadership of the society (Devkota, 2019; Dhital, 2020; Kharel \& Tharu, 2019). It would be a hurry to evaluate the effectiveness of Nepal's federalism and its delivery to change the local power structure as the practice has just spanned only three years of implementation since the elections held in 2017 for all tiers of government. There are contradictions amidst opportunities and challenges. On the other hand, however, the issues of morality, responsibility, leadership, and elitism are becoming more prominent issues in research. One of them is the leadership crisis. In this regard, different arguments and contestations have been highlighted by different authors. For example, Devkota (2019) maintains that lack of decisiveness in the leadership has eventually derailed the declaration of the republic system in the country. He would call it a leadership crisis (2019, p. 50). Interestingly, however, he concludes that if leaders were daring to declare the republic since the last century, Nepal would have been much developed, and much matured in politics. Despite posing this predicative hypothesis, he fails to offer sufficient evidence to support his argument. This school of thought takes political factors (leadership, parties, and the movements) as a one and ultimate solution to all the problems existing in the country.

Second, there is a meta-theoretical school which perceives that leadership crisis as a consequence of a morality crisis. Dhakal (2020) would call it a decline in the moral foundations of Nepali politics. The core of this argumentation remains in the morality of leadership to be analyzed in the worldviews of representation and ethics. Calling this dilemma in the Nepali context, Dhakal further argues that the latest political development in Nepal prominently displays sheer deviation from the minimum political ideology, values, and morality. In this context, the urgency to chalk a return path to inclusive and participatory politics (p.2).

Third, there is another school of thought which also perceives leadership crisis, though it wants to address other micro-level issues of development, remittance, livelihood, modernization, and local narratives of the crisis. Though this school of thought is less theorized, it focuses more on the causes of underdevelopment. To cite a representative example:

The concept of "New Nepal" was born to bring drastic socio-economic transformation progressively through agrarian reform and then developing productive forces and industrial relations to provide youth employment. But the existing structures and institutions neither function 
accordingly nor seem to have the desired capacity and will-power to bring the desired changes (Sharma, Upreti, Manandhar \& Sapkota, 2014, p. ii)

It is very crucial to note that very few studies are done on leadership and power relations in Nepal's -postconstitutional context of federalism. In sum, there are some critical research issues and gaps to visualize rural society in terms of changing leadership and power relations. They include, but not limited to:

- Changing pattern of rural leadership

- Power structure of rural society

- Diversification of rural livelihood

- Changes in caste/ ethnic relations

- Changes in power, voices, and practices of marginalized communities, including the Dalits and women

- Rural-urban continuum versus rural-urban dichotomy

- Local-provincial-federal governments implications on power exercise (co-operation and conflict)

- Changes in class positions and its nexus to caste/ ethnic and regional attributes

- $\quad$ Emergence and role of rural elites

- Party politics, non-state actors, and social movements in rural areas

\section{Materials and Methods}

Within a mixed-methodology approach, this study follows an ontological position of critical design. This approach arguably seems more rational in the studies dealing with power and subject dynamics of society (Creswell, 2013). The mixed-method is followed in the present study as the power and leadership are subjective though they could have been affected by and constructed with some objective facts or attributes. Ward No. 3 of Suddhodhan Rural Municipality was purposively selected as a study site, which lies in the Rupandehi district of Lumbini Province. According to Census 2011, this rural municipality had 34638 population (6145 $\mathrm{HHs}$ ), and ward 3 bears 4614 population in total (having 2114 male, 2500 female, and $980 \mathrm{HHs}$ (CBS, 2012). The study was based on a set of field level primary data collected from the respondents with the help of an interview schedule. The head of each household in the study village was the population of the present study. The data were collected during the period from August to December 2019.

Methodologically, the study is a case-study design as it is based on the empirical world of Suddhodhan RM and in Dogana village. Within the mixed-method approach, a case study is assumed to be the in-depth study of a particular research issue (Gomm, Hammersley, \& Foster, 2000; Mills, Durepos, \& Wiebe, 2010; Yin, 1994); hereby the case of leadership and power structure in a defined politicaladministrative unit of Suddhodhan RM. A household survey was conducted for the collection of quantitative data. The ward was first divided into three clusters based on caste/ ethnicity and their dominant settlement pattern (Brahmin/ Chettri, Janajati including Tharus, and Dalits). In each of the clusters, the researcher randomly selected 30 households, and thus, there were 90 Households selected in total for the HH survey and they had been considered as analytical units. After collecting requisite data, they were edited, and then the edited data were compiled, classified, tabulated, and analyzed by using SPSS (Statistical Package for Social Sciences). For analysis and presentation of data different statistical tools like percentages, ratios, mean, etc. were applied and weighted score and rank order also used.

As a part of the qualitative tools, six in-depth interviews were conducted with the prominent leaders, two Focus Group Discussions were done among the concerned stakeholders and a case study of a renowned social leader was also done. For these kinds of qualitative inquiry, 16 rural leaders were identified and followed for further inquiry. Both the qualitative tools and quantitative tools were concurrently followed in the field. In doing so, the tools were triangulated to increase the trustworthiness of the findings. For example, the perception of local leaders and people has been contrasted/ compared to reflect how they perceive power holding in different ways. The findings of the quantitative survey were statistically operated with SPSS while the responses collected from the interview and group discussions were first manually coded and then proceeded with narrative analysis. Ethically, the study has adopted the principles of privacy, anonymity, cultural respect, and academic integrity.

\section{Results and Discussion}

\section{Historical trend and recalling of the research participants}

The present study found a significant shift in power structure and exercise of an enormous influence on rural societies in Nepal. Before the unification of Nepal, the local power structure was laid more on the locally nominated leaders (samanta and mahasamanta) on the people's consensus and approval of the central government. However, as some studies reveal, the power structure of Nepali society in the last two centuries remain predominantly feudal (Regmi, 2002). Eventually, it created inequality that began to be structural in the agrarian rural economy of Nepal. It is primarily the landbased hierarchy that continues till today (Sapkota, 2016). However, it is important to note that some indigenous practices of leadership and social welfare at the local level also got continued in different forms in different regions of the country. These include parma, pareli, dhikuri, jhora, badghar, bajan mandala, praganna, and dharma bhakari (Sapkota \& Tharu, 2015). Economic, social, cultural, infrastructural, and political development made a radical change in the people who held the power earlier. This study reveals that the Bahun-Chhettri enjoyed supremacy over the general people of Dogana and the neighboring village for a long time. As the research participants revealed that most of the Tharus had earlier a larger chock of agricultural land. However, they gradually sold the land at a very cheap 
price to the new migrants who started to come to settle in the region, most of whom were hilly upper caste groups (Bahun/Chettries) followed by janajatis (Magar and Gurung) and the Dalits in few numbers. This continued till recently, though there is another fact of losing the land that the Tharu native people could not get benefitted much with their traditional agricultural practices insulated with subsistence-based production practices.

As stated earlier, though the local Tharu people were in majority till the 1970 s, a massive trend of migration from hill to Tarai region started with the eradication of malaria and typhoid in the region. Historically, a strong socioeconomic status, demographic strength, control over huge agricultural land and forestry were the sources of power for the Tharus till the 1970s. The power structure particularly after 1990 could not represent the Tharus as mainstream. However, many research participants including the Tharus revealed that the village is well developed after the arrival of hilly people and settling there in the region. This settlement, in turn, contributed to flourishing a diverse structure of livelihood, culture, and development.

Badhghar (also known as bhalmansa, aguwa, mahatwa in different regions) is a well-known social control and leadership development system among the Tharus in the Tarai region. As of no exception, there was a Badhghar system in the village (in all settlements) where the people used to select their head of settlement in a consensus before 1990. These Badhghars were granted different kinds of rights, duties, and responsibilities, including maintaining agricultural services, managing community conflicts, and lead the community in many aspects. Though this system was not politically recognized, the existing political system (Panchayat) did not collapse it and allowed to exist it as the Badhghars could not affect or engage in the larger political issues beyond their respective communities/ settlements. As the migration trend increased from Hill to Tarai, it then paved the way for the favor of non-Tharus to hold the position of leadership and socio-economic status in the villages. Moreover, while talking about other indigenous practices of the Tharus in the village, a few respondents with comparatively older age generation recalled that they had Bakhari system as a saving of annual production. It operated till 197Os. Besides, there was Mahajani system in the community which served as a microcredit organization in the Tharu community. However, it ended even before the Dhama Bhakari system.

The power shifting continues till the 1990s, even though there were elected local representatives and the practice of the Badhghar system simultaneously. The research participant shared very confidently that there was no conflict between these two institutions in the village. The most important thing in this regard was that the Badhghar system was well grasped and adapted both by the Tharu and non-Tharu, and it is interesting to remark that once the Badhghar of Dogana village was elected from the non-Tharu community as well. Unfortunately, with the rise of the Maoist conflict in the country neither the local bodies got elected nor the Badhghar system could get continuation since the late 1990s. With the fall of the Badhghar system, traditional local structures of power gradually weakened. Moreover, it paved the way for identity politics. The identity politics has been analyzed by many studies and there are different arguments in terms of the Tharu movement. Meanwhile, Sapkota defined it as a contested notion and has referred to it as a 'degenerated leadership' (Sapkota, 2014). He further concludes that the identity politics entered as just western propaganda, which would not offer any kinds of emancipation to the Tharus (Sapkota, 2017).

\section{Recent Dynamics of Leadership and Power Structure}

\section{a) 2000-2015}

The dramatic change occurred in the power structure of Dogana village as well as rural Nepal during the decadelong Maoist insurgency (1996-2006). The movement was a broad spectrum of social mobilization that though violently advocated people's grassroots issues for which the central government was almost reluctant. It contributed to increasing political awareness among the rural poor including the marginalized communities. However, the way of people's mobilization from the Maoists into different caste/ethnic wings and regional territory is highly debated in contemporary sociological studies. Thus, the Maoist movement could not be said to be a historically phenomenal revolution led by the proletariat in a pure Marxist perspective. It would require further academic debates and researchers involving multidisciplinary notions of politics, economy, social and cultural change, and leadership development. Particularly after 2000, there was no formal political leadership in the villages and the village administration was vacant due to the ending of the tenure of local election in 2002. In this village, no ward citizen forum and all party mechanism could work as provisioned by the central government. Nor the Maoists themselves engaged in the issues of rural development, community enhancement, and people's mobilization. However, during the field study, ten people reported that they had once joined the Maoist movement. And, to an utter surprise, none of them now belonged to the party though the number of Maoist supporters could have been increased in the last two decades,

The rural people experienced a quite different leadership change from informal to formal; non-political to political; and less inclusive to more inclusive. For this, the role of the Local Self Governance Act (1999) seems quite a mile stoning which institutionalized inclusive leadership at the grassroots level. Before this, a representative legal system was already employed in the elections of local bodies held in 1997where the presence of at least one woman and one marginalized community representative was a mandatory provision. However, people have different perspectives in owning such a political change that they got with the local elections and different kinds of political and social movements. What they expected, contributed/ sacrificed as such and what they have now got in turn seems one of the 
dilemmas in this regard. This is just a similar context as to how Toch (2013) recalls that social movements often grow with breeding hopes but end with tragedies.

The tragedy seems to also evident in the field of this study. The research participants said that the implementation of the parliamentary system of government could not make any significant changes in the national and rural political structure. This simply indicates that there are no significant improvements in sustaining people's livelihood, increasing agricultural productivity, and ensuring equity and justice. However, they agreed with the changes in the education and health sector and also with the expansion of cooperative and micro-credit schemes in the village. Again they expressed that the implementation of micro-credit and income-generating development programs in the study village by the NGOs and government organizations created significant cash earning class in the village. Of course, the emergence and practices of cooperative and microcredit systems in Nepal go a long back ago, but it is also evident that the number of these institutions mushroomed after 1990 and more massively after 2006. The expansion of education for all also created a new opportunity to participate in the formal and informal local power structure.

However, these changes at the grassroots level have been largely brought by the flow of the remittances rather than by the increase in the internal production system of the country or the gross domestic product. Young and educated persons started to participate in the decisionmaking procedures both at household and community levels. Indeed, there is a kind of romanticism that claims as if all the changes in the country have been brought by the political changes in the leadership of the political parties. This school of thought does not count the people who may vote for any political parties but remain out of party politics and never truly trust in political parties/leaders. On the other hand, modernization as a shadow of globalization has brought tremendous changes in Nepali society that is also not exceptional to Dogana village where this study was employed.

To follow with, the People's Movement 2006 paved the way for mainstreaming the Maoist movement into parliamentary politics thereby eliminating the centuriesold monarchial system in the country. Of course, it is ever questionable -and perhaps the most difficult to answer-the cause-effect dynamics of these important events in Nepali polity. Nevertheless, the state thereafter formally entered into the inclusive agenda of development in favor of marginalized groups and regions. Moreover, NGOs activities and their microcredit programs expanded gradually up to the rural areas and these activities helped the rural people to create income-generating activities. As evident in the Dogana during the study time, four NGOs were working in the women and agriculture sector and two saving groups, and one co-operative. However, the situation got more conflicting than making any marked changes in the landscape of rural development and power structure in society. As one of the leaders from Siyari tole of Dogana reflected that the leadership in the village has been drastically changed along with the rise of many organizations and groups in society. To continue:

There were just two or three parties [political] and a few leaders in the village before 10 or 15 years ago. But nowadays I see that we [leaders] represent many political parties, social organizations, and non-governmental agencies. Even some leaders belong to the government's bureaucracy. People support and join us as per our engagement with public issues and general welfare. [Based on a personal conversation of the researcher with a research participant, 16 December 2019]

This type of increase in the leaders has led to greater competition in power exercise but could have a good platform for advocacy, political referendum, and people's representation. Such representation was well imagined in various public spheres of participation, including the School Management Committee of Janajyoti LSC, Gaun kulai samiti (irrigation) in different toles, management committees for different temples and religious sites (particularly the Siayari Mai), and the ward executive (Ward no. 3 of the Suddhodhan RM) itself. Despite this, there are some reflections of people that narrated their disagreements and disregards the mainstream political parties and their leaders. One of the respondents from Bagiya tole in the village, therefore, reflected: there is nothing different to vote this political party or that, and to choose this leader or that. It indicates that there were contradictions in the mainstream political leadership that could not address the expectations of people. It further reflects people's disagreement with the existing pattern of political leadership, their responsibility towards people, and the way of governance they are offering in the name of democracy.

\section{b) Changes after 2015}

In September 2015 Nepal got a new Constitution and it introduced a federal republic system in the country. The Dogana village which previously belonged to Pharsatikar Village Development Committee now falls in Suddhodhan's rural municipality when the state was restructured into 7 provinces and 753 local units as per the new constitution. The three tiers of government were fulfilled through the elections held in 2017 in different phases for the federal and provincial level and the local. The local levels, in particular, were vacant since 2002 which hampered to flourish of grassroots democracy and political representation very badly. This election, therefore formally established representative leadership in the village, and different kinds of administrative services have been available in the ward office itself. As per the constitutional provision, the local units were fulfilled with an inclusive set of representatives (including the mandatory provision of women and marginalized community/ Dalits) after a 15 year vacant. The research participants found very much optimistic about this kind of new political system in the federal context. The hopes and expectations could have risen among the people due to different political-economic causes. 
For example, the people became a witness of long decade Maoist armed insurgency which echoed as an uncertain threat of violence, and they were also suffered from the vacant local representative and distorted service delivery system in the village. All the miseries could have been rolled into a single cream that they will be resolved all of sudden by offering all-time emancipation to the people and country. As such Maoist movement was dreamed out, following the glorification of the People's Movement 2006, ending of Monarchial system, writing of the new constitution through people's representatives, adoption of the federal system in the country, and delineation of central administration into the village levels (gaun gaunma singh durbar).

Politically, it is right for autonomous people to be dreamed out, but the ethical questions in this regard always go to the leadership as to what types of dreams and slogans have been inserted to the people and in what way they will be fulfilled and satisfied so far. Empirically, Dogana village is no exception to this. The people have got many governmental services within their nearby administrative premises of the government, in the ward office (Dogana) in most of the cases and the Rural Municipal office (Manpakadi) in few cases. The leaders used to be easily assessed and people's voices got largely manifested. Apart from these services and hopes, there is another tragic part of the story. The increase in the tax system, elite centric nature of the elected leaders, and increasing cases of corruption are the main causes that triggered the hope into despair. In particular, the amounting value of tax for the services has been a burden for the poor service recipients. Thus, the hopes and despair came into a paradox. To put a reflection from the ward chair in this regard:

People have got many things in their door from citizenship cards to others. The constitution has given us many things us, and we got the opportunity to lead the people's issues. However, I feel confused as we have yet to formulate many supportive policies in this regard. Many people come to me and keep their complaining that the service charge of the services adhered by this rural municipality has been too much expensive, though it seems cheap as compared to the others. Moreover, they complain that development activities have not been conducted as they had expected before the elections. I think it takes time and they have no options other than wait and see. [Based on a personal conversation of the researcher with a research participant, 4 November 2019]

However, the analysis of the elections shows that the candidacy from all parties was most favorable for the rich people, upper caste people, and the person who seem close to the established figure of the national parties. This situation virtually distorts the power structure of villages in favor of upper-class rich people, power elites, and vested groups. To reflect a local narration from Tharu tole of the village:

We [Tharus] could not take part in the candidacy of the elections due to lack of money. Though we are a reserved vote bank for any of the political parties to affect the results of the elections, most of us don't like to engage in politics as there has been upper caste domination as well as we have poor economic status and educational attainment. This is more clearly seen in the recent elections where even ward members had to spend more than 10 lakh rupees. What could a poor do then if he [or she] fails to win the election? Nothing! [Based on personal conversation of the researcher with research participant, 16 December 2019]

\section{c) General status of the leadership:}

Leadership is an essential part of the power structure in society. This study assumes that leadership is socially constructed and structured. Of course, political parties are assumed to be the founding platform of leadership development. However, leadership is developed from multiple sources and sectors in this changing world. It is largely influenced by globalization and coupled with the continuum of modernity and post-modernity. Despite this fact, there is an important dynamics of how is this leadership constructed and what its general status is. Demographic variables of the research participants give some insight into the social and economic background of the rural leadership in Dogana village. Table 1 shows the general demographic background of the leaders in terms of their age, educational status, occupation, and caste/ ethnicity.

Table 1: Socio-economic and political background of rural leaders

\begin{tabular}{|c|c|c|}
\hline Variables & Frequency & Percentage $(\%)$ \\
\hline Total & 90 & 100 \\
\hline \multicolumn{3}{|c|}{ 1) Age Group (yrs) } \\
\hline $20-40$ & 40 & 44.5 \\
\hline $41-55$ & 35 & 38.9 \\
\hline 56 and above & 15 & 16.6 \\
\hline \multicolumn{3}{|c|}{ 2) Education } \\
\hline Illiterate & 1 & 1.2 \\
\hline Primary (1-5 ) & 18 & 20 \\
\hline Secondary (6-10) & 47 & 52.2 \\
\hline Intermediate level & 16 & 17.7 \\
\hline Graduate and above & 8 & 8.9 \\
\hline \multicolumn{3}{|c|}{ 3) Occupation } \\
\hline Agriculture & 50 & 55.6 \\
\hline Business & 16 & 17.7 \\
\hline Service & 7 & 7.7 \\
\hline $\begin{array}{l}\text { Mix (Ag., service+ } \\
\text { business) }\end{array}$ & 11 & 12.2 \\
\hline Others & 2 & 2.2 \\
\hline \multicolumn{3}{|c|}{ 4) Caste/ ethnicity } \\
\hline Brahman/ Chettri & 29 & 32.2 \\
\hline Adivasi/ janajati & 45 & 50 \\
\hline Madhesi & 8 & 8.9 \\
\hline Dalits & 5 & 5.55 \\
\hline Others & 3 & 3.3 \\
\hline
\end{tabular}


Source: Field Survey, 2019

Age-group variables indicate that most of the leaders were relatively young and it has a decreasing trend after 40 years of age. The community members having average level of educational attainment (i.e. secondary level) were dominating by $52.2 \%$ in the community leadership, followed by the leaders having primary level $(20 \%)$ and intermediate level $(17.7 \%)$. While the leaders having graduated have less engagement $(8.9 \%)$ in the leadership, it is also interesting to note that there was one illiterate leadership out of the total 90. This type of educational attainment reflects that the leadership is still not developing along with the educational entitlement, rather it could have followed with other attributes, including income, age, and caste/ ethnic background. Most of the educated youths did not perceive politics and leadership for their long-term career, though a few have had close intact with politics and power. In the study village, it was found that the majority of the leaders were farmers and they engage in agricultural activities (55.6\%), followed by business persons $(17.7 \%)$, mixed types of professionals (12.2\%), and service holders $(7.7 \%)$ leaders.

This reflects a structure of occupation distribution of the leaders in a rural context where the dominance of agriculture is in decreasing trend as reflected in the interview with them due to livelihood diversification and importance of cash income to attain the power in terms of social prestige and politics. In terms of caste/ ethnicity, it is evident that almost 50 percent of the leaders belonged to the indigenous group (Aadibasi/ Janajati), on which the Tharus are dominant in Dogana. A few of them were Magars and Newars. Following them, there were Brahmin and Chettri leaders (32.2\%). The presence of Madhesi and Dalit leaders was also marked as such, $9 \%$ and $5.5 \%$, respectively, which might be due to the demographic composition of ward 3 and mandatory policy of inclusion adhered by the Government of Nepal. It is therefore important to assess further studies to analyze whether the domination of a particular caste/ ethnic group contribute to leadership development and power-sharing or not.

\section{d) Factors influencing rural leadership}

There are many different factors to affect the rural leadership and their power dynamics, ranging from focusing on the personal traits or merits, situations granted, and other social-structural conditionality. Like most things, leadership is a highly multi-faceted subject and it is a mixture of many factors to push through and pull to it at times. The study findings suggest that there were several factors in the case of holding the rural leadership. An attempt was made to determine the most pertinent factors in this regard. Methodologically, priorities over the third rank have been omitted here in the table though the total weightage is cumulated out of all kinds of priorities maintained by the research participants based on which final rank has been asserted.

As reflected in Table 2, it is found that the first and foremost factor in the case of holding the rural leadership was 'affiliation with the political party'. It indicates that the political parties are more popular and powerful to generate or affiliate the leadership in the village. The second important factors in this respect were 'wellbeing ranking' and 'caste/ ethnic status' as both have an equal total weightage of 80 out of the total priorities given by the research participants during the survey. The merit of personal qualities and traits has third ranking in aggregate with a score of 68 in total, followed by a level of educational attainment ranking fourth and professional background ranking fifth.

Table 2: Factors Responsible For Rural Leadership and Holding Power

\begin{tabular}{|l|c|c|c|c|c|}
\hline \multirow{2}{*}{} & \multicolumn{3}{|c|}{ Priorities } & $\begin{array}{c}\text { Total } \\
\text { weight- } \\
\text { ed }\end{array}$ & $\begin{array}{c}\text { Fi- } \\
\text { nal } \\
\text { rank }\end{array}$ \\
\cline { 2 - 6 } & I & II & III & Score & $\begin{array}{c}\text { Or- } \\
\text { der }\end{array}$ \\
\hline Caste/ ethnic status & 20 & 18 & 14 & 80 & II \\
\hline Level of education & 19 & 17 & 15 & 65 & IV \\
\hline $\begin{array}{l}\text { Professional back- } \\
\text { ground }\end{array}$ & 17 & 11 & 14 & 63 & V \\
\hline $\begin{array}{l}\text { Affiliation with polit- } \\
\text { ical party }\end{array}$ & 20 & 13 & 12 & 85 & I \\
\hline Well-being ranking & 17 & 18 & 10 & 80 & II \\
\hline Age & 14 & 13 & 8 & 62 & VI \\
\hline Personal qualities & 19 & 15 & 18 & 68 & III \\
\hline Others & 3 & 2 & 2 & 18 & VII \\
\hline
\end{tabular}

Source: Field Survey, 2018/019

Here, it is to be analyzed the leadership dilemma in terms of qualities and characteristics. Indeed, as argued by De Wijze (2019), in some morally conflictual situations, politicians do wrong to do the right things for the general welfare, though there is a risk of leading to the consecutive continuum of the 'dirty hands'. It appears that the rulers have tried to change the political course following their ease, whims, and immediate benefits. The frequent changes of some elites who often enter into different political parties in the study area also support this dilemma. Moreover, the ruling party or a few power elites perform such actions usually to protect their traditional power and hegemonic supremacy. Ely, Meyerson, and Davidson (2006) critically observe that when self-protection becomes more important than the work for the public good, the credibility, connections with people, and risk-taking ability of the leadership eventually get collapsed. As Dhakal (2020) concludes, this seems to be the current reality of Nepali rulers, who have largely failed to adopt politics as a selfless service to the public mass.

\section{e) Leadership and well-being ranking}

In the present time, the rural power structure comprises all the new classes and groups significantly as per their active participation. As reflected in the qualitative inquiry 
(interview and FGDs), the researcher engaged with 15 leaders to the depth. Accordingly, the leaders of two types as evident in the field visit.

The first category was the position holders with social status. This category of rural leadership was used to identify those persons who hold some positions of authority and formal power in institutions and organizations of the community. Adopting the approach, 6 positional leaders were found in the study area. Among these positional leaders, 2 were local political leaders, 2 were NGO leaders and 2 were institutional leaders. Second, the category of reputation holders without having a formal position also existed. These leaders have had a reputation but no formal position of authority and they exerted enormous power and influence in village affairs. There were 9 leaders selected as such, among these 2 were local teachers, 4 were largescale farmers and 3 businesspersons. The well-being ranking of the leaders also affects the power relations in leadership development. Keeping this proposition, a well-being ranking was done both in the quantitative data collection HH Survey and during the semi-structured indepth interviews among the leaders.

Table 3: Well-being ranking status of leaders

\begin{tabular}{|c|c|c|c|}
\hline $\begin{array}{l}\text { Rank- } \\
\text { ing } \\
\text { status }\end{array}$ & Indicator & $\begin{array}{l}\text { Quan- } \\
\text { tita- } \\
\text { tive-HH } \\
\text { survey } \\
\text { (N) }\end{array}$ & $\begin{array}{l}\text { Qual- } \\
\text { ita- } \\
\text { tive-In- } \\
\text { ter- } \\
\text { views } \\
\text { (N) }\end{array}$ \\
\hline $\begin{array}{l}\text { Upper- } \\
\text { most }\end{array}$ & $\begin{array}{l}\text { Having land-holding more } \\
\text { than } 2 \text { bigha; } 2-3 \text { residen- } \\
\text { tial plots; well-concretized } \\
\text { house; supplement occu- } \\
\text { pation than the leadership, } \\
\text { including land plotting, bid- } \\
\text { ding or in industry }\end{array}$ & 6 & 3 \\
\hline Rich & $\begin{array}{l}\text { Having land-holding of 1-2 } \\
\text { bigha; well-concretized } \\
\text { house; } 1-2 \text { residential plot; } \\
\text { supplement occupation than } \\
\text { the leadership including any } \\
\text { kinds of large business }\end{array}$ & 20 & 6 \\
\hline Middle & $\begin{array}{l}\text { Having land-holding more } \\
\text { than } 10 \text { kattha-1 bigha; } \\
\text { well-concretized house;1-2 } \\
\text { residential plot; other occu- } \\
\text { pation than the leadership } \\
\text { including any kinds of small } \\
\text { business }\end{array}$ & 45 & 5 \\
\hline Poor & $\begin{array}{l}\text { Having land-holding of less } \\
\text { than } 10 \text { kattha; loose(mud) } \\
\text { type of house structure; no } \\
\text { any residential plot; and no } \\
\text { any extra occupation }\end{array}$ & 12 & 2 \\
\hline $\begin{array}{l}\text { Ul- } \\
\text { tra-poor }\end{array}$ & $\begin{array}{l}\text { Having no land-holding; } \\
\text { loose type of house struc- } \\
\text { ture; no any residential plot; } \\
\text { and occupation }\end{array}$ & 7 & - \\
\hline Total & & 90 & 16 \\
\hline
\end{tabular}

Source: Field visit, 2019
As reflected in Table 3, the ranked categories were five-folded which were self-declared by the research participants in prior information of respective indicators for each of the categories. They include uppermost, rich, middle, poor, and ultra-poor. The HHS shows that middle-class leadership was of almost 50 percent out of the total $90 \mathrm{HHs}$ followed by the strata of rich $(22.3 \%)$ and poor (13.4\%). The interviews and discussions among the purposively selected 16 respondents further reveal that rich class people were dominant (37.55) slightly than the middle-class people (31.3\%). There were no leaders from ultra-poor rank during the interview though the survey shows that 7 leaders belonged to ultra-poor ranking. All these figures reflect that there was a domination of upper ranked people in the leadership position that would play more power exercises to control their interests through the formation of elite-centric alliances. Consequently, it has led to an exploitation of the poor class people in many respects, which were evident during the group discussions.

Taking this retrospect, we should question the leadership crisis in terms of its political, social, and economic spheres. Nevertheless, leadership is a multidimensional construction; and therefore, its crisis, narratives, and issues are also diverse. De Wijze (2019) raises a relevant question: are politicians so stupid that they are not aware of the public views of their actions and thus they continue acting in ways that the general public perceives as irrational, irrelevant, ill-timed, and deeply problematic? Rhetoric maintains that the answer should be 'no', as leaders are assumed to be good and pure. However, it is contested that the seemingly good politicians have often turned more power monger, self-serving, and 'legitimacy seeker' once they are in power. Besides, they lose "political honesty" and thus no one would be ready in taking responsibility for their bad actions (De Wijze, 2019). It is further contributing to leading to the loss of the sense of accountability as well. In Nepal's context, Dhakal (2020) therefore rightly concludes that:

Although we may not expect morality politics from the existing heads of major political parties, revamping the party structures, meritocratic selection in the constitutional bodies, empowering the parliament, and strict adherence to the rule of law and 'evidence-informed policymaking' (Dhakal, 2019) will ensure that the lost morality in Nepali politics can be revived and rejuvenated (p.7).

\section{Conclusion}

The crucial insights and findings that emerged from this study are quite surprising in the context of the local power structure and village politics in Nepal. This study found that the rural power structure and the pattern of leadership have undergone an important change - now it is not rigid as it was in the past. The leadership is becoming inclusive and structurally becoming diversified and multifaceted. It has been shifted from informal to formal, thereby attracting youths and marginalized communities including women, Tharus, and Dalits. The introduction of the formal leadership since the 1990s (with electoral democracy), 
the rise of Maoist conflict (1996-2006), and the initiation of different kinds of rural/ community development projects have largely contributed to changing the power structure of Dogana village. National party politics after the People's Movement 2006 and the promulgation of the new Constitution in 2015 also affected the development of the local leadership. However, the federal delineation (particular to the local government) is yet to connect with the strategic policies and action plans that have been adhered to in the Constitution (Annex 8 and 9). Moreover, the principles of governance and its reflection on the performance of leadership and power-sharing is a very critical aspect of the effectiveness of the local service delivery system in the villages.

However, in terms of class structure, it is still oriented by upper-class people including the elites. The taboo of caste/ ethnic belongingness (i.e. jatibaad), regionalism (particular preference to tole or settlement), expensive nature of electoral campaigns, and undue importance of party politics (favoritism as a blind dedication, i.e. jholebad) are factors that have deteriorated contemporary leadership and power-sharing in the villages. Without any doubt, it is well narrated in the field that the local services have been reached to the household levels of people consuming less time and distance, but the tax system does not favor the common people who hold less control over the existing power structure in the village. It is evident that most of the people were divided into different political parties according to their lineage, ideology, and occupational background.

Moreover, deterioration of morality and ethics of the leadership and recycling of the traditional power elites have largely distorted the leadership structure of society. It is thus high time to develop and restructure the leadership crisis through representation and participation of the most dissenting actors of politics, development, and social change in the society. In sum, it can be concluded that rural leaders with their younger age, higher education, personal qualities, political affiliation, and other traits were available to gain their ascendancy in the village power mechanism. It is therefore the risk of emergence of new elites in the name of leadership cannot be neglected with which the power structure would be highly knotted.

\section{Acknowledgments:}

I thank local people and their representatives of Dogna Village of Suddhodhan Rural Municipality, Rupandehi for their kind help during my stay for data collection. Moreover, a sincere credit also goes to the anonymous reviewers for their careful reading of my manuscript and their insightful feedback.

\section{Funding:}

The research was not financed by any grants of elsewhere. Conflict of Interest: I do not have any conflict of interest for this study, nor for the publication.

Originality: I also declare the originality of the research in terms of the data and contents.
Ethical Conduct of Research:

I declare that the study was conducted ethically, maintaining the privacy of sensitive data, maintaining cultural respect, and promoting academic integrity.

\section{References}

Bista, D. B. (2008). Fatalism and development: Nepal's struggle for modernization. [1st ed., 1991]. Orient Longman.

Bourdieu, P. (1977). Outline of a theory of practice. Cambridge University Press

Bourdieu, P. (1979/1984). Distinction: a social critique of the judgement of taste. Routledge.

Central Bureau of Statistics [CBS]. (2012). National population and housing census, Vol. I \& II. Central Bureau of Statistics, Government of Nepal.

CIMA (2001). Leadership skills - An overview [Technical Brief]. Chartered Institute of Management Accountants. Retrieved from https://www.cimaglobal.com/Documents/ ImportedDocuments/leadershipskillsoverview techrpt 0501.pdf

Constitution of Nepal (2015). Nepal law commission. Government of Nepal.

Creswell, J. W. (2013). Research design: Qualitative, quantitative, and mixed methods approaches (4th ed.). Sage.

Devkota, K. (2019). Leadership Crisis in Nepali Politics: Specific Focus on National Parties in the Context of Declaration of the Republic [Discussion Paper]. Social Inquiry: Journal of Social Science Research, 1(1), 42-51. Retrieved from https://doi.org/10.3126/ sijssr.v1i1.26915

De Wijze, S. (2019, May 20). Can politicians be moral? Retrieved from https://iai.tv/articles/how-shouldwejudge-politicians-auid-1236

Dhakal, R. K. (2019). The politics of education policymaking in Nepal. Journal of Education and Research, 9(1), 1-12.

Dhakal, R. K. (2020). Decline in the Moral Foundations of Nepali Politics [Editorial]. Social Inquiry: Journal of Social Science Research, 2(1), 1-10. https://doi. org/10.3126/sijssr.v2i1.28902

Dhital, B. (2018). Local Governance Practices in Federal Context: The Case of Gorkha Municipality. Nepalese Journal of Development and Rural Studies, 15, 11-22. https://doi.org/10.3126/njdrs.v15i0.31591

Ely, R. J., Meyerson, D.,\& Davidson, M. N. (2006, September). Rethinking political correctness. Retrieved from https://hbr.org/2006/09/ rethinkingpolitical-correctness

Foucault, M. (1982). The subject and power. Critical inquiry, 8(4), 777-795.

Frohlich, N., \& Oppenheimer, J. A. (2015). Political leadership and collective goods (Vol. 1298). Princeton 
University Press

Garfield, Z. H., von Rueden, C., \& Hagen, E. H. (2018). The evolutionary anthropology of political leadership. The Leadership Quarterly. 30(1), 59-80. https://doi. org/10.1016/j.leaqua.2018.09.001

Geiser, U. (2014). Conceptualizing 'contested development' - from grand narratives to the nittygritty of the everyday. In S.R. Sharma, B.R. Upreti, P. Manandhar, \& M. Sapkota (Eds), Contested Development in Nepal: Experiences and Reflections (pp. 1-25). School of Arts, Kathmandu University and Nepal Centre for Contemporary Research (NCCR).

Girardin, B. (2012). Ethics in politics: Why it matters more than ever and how it can make a difference. Globethics. net.

Gomm, R., Hammersley, M., \& Foster, P. (Eds.). (2000). Case study method: Key issues, key texts. Sage.

Gramsci, A. (2009). Selections from the prison notebooks. Q. Hoare, N.M. Geoffrey, (Eds./ Trans.) London: Orient BlackSwan.

Jones, A. M., \& York, S. L. (2016). The fragile balance of power and leadership. The Journal of Values-Based Leadership, 9(2), 11.

Kharel, S., \& Tharu, M. (2019). Service Delivery Practices of Local Government in Federal Nepal. Nepalese Journal of Development and Rural Studies, 16, 83-93. https://doi.org/10.3126/njdrs. v16i0.31575

Lawoti, M. \& Pahari, A. K. (2010). (Eds). Maoist Insurgency in Nepal: Revolution in the twenty-first century. Routledge.

Martins, N. O. (2018). An ontology of power and leadership. Journal for the Theory of Social Behaviour, 48(1), 83-97.

Mills, A. J., Durepos, G. \& Wiebe, E. (2010). Encyclopedia of case study research. Sage.

Mills, C. W. (1956/2000). The sociological imagination. Oxford University Press.

Mishra, C. (2011). Capitalism and Nepal [in Nepali]. Fine Print Books.

Mozumdar, L., Ali, R.N., Farid, K.S., \& Kabir, M.S. (2008). Changing leadership and rural power structure. Journal of Bangladesh Agricultural University, 6(2): 429-436.

Nabers, D. (2016). Power, leadership and hegemony in international politics. In Regional Leadership in the Global System (pp. 63-82). Routledge.

Prabhu, M. (2019). Chanakya Kautilya: Understanding the colossal genius. VIVASWAAN.

Pradhan, R. (2011). Ethnicity, Caste and a Pluralist Society. In K. Visweswaran (Ed.), Perspectives on modern South Asia: A reader in culture, history, and representation (pp. 100-113). Wiley Blackwell

Regmi, M. C. (1979). Readings in Nepali economic history. A collection of various notes and articles published for the most part in Regmi Research Series.
Kishor Vidya Niketan.

Regmi, M. C. (2002). Nepal: An historical miscellany. A collection of his various notes and articles published for the most part in Regmi Research Series. Adroit Publishers.

Sapkota, M. (2014). “Degenerated” Leadership of Social Movements: Implications from the Tharu Movement in Nepal. International Journal of Sciences: Basic and Applied Research, 17(1), 29-38. http://gssrr.org/index.

Sapkota, M. \& Tharu, M. (2015). Sustainable Community Development: A Critical Review. Nepalese Journal of Development and Rural Studies, 12, 66-78.

Sapkota, M. (2016). Public land movement in Nepal: Expanding coverage and diminishing achievements. New Angle. Nepal Journal of Social Science and Public Policy. 4(1), 69-87.

Sapkota, M. (2017). Rise of ethnic movements and contested development in Nepal: A case study of the Tharu movement. (An unpublished $\mathrm{PhD}$ Thesis). Kathmandu University, School of Arts, Kathmandu, Nepal.

Seddon, D., \& Hussein, K. (2002). The consequences of conflict: Livelihoods and development in Nepal. Overseas Development Institute.

Sharma, S. R., Upreti, B.R., Manandhar, P., \& Sapkota, M. (eds.). (2014). Contested development in Nepal: Experiences and reflections. School of Arts, Kathmandu University and Nepal Centre for Contemporary Research (NCCR). Retrieved from http://www.kpsrl.org/uploads/debatten discussies/2014_sharma_et_al_2014_contested development in nepal.pdf

Thiele, L. P. (2019). Post-sovereign power and leadership. Contemporary Political Theory, 18(2), 158-179.

Thompson, D. F. (2019). Political ethics. In H. La Follette (Ed.), International encyclopedia of ethics (pp. 1-11). John Wiley \& Sons.

Toch, H. (2013). The social psychology of social movements (Psychology revivals). Routledge.

Whelpton, J. (2005). A history of Nepal. Cambridge University Press.

Yin, R. (1994). Case study research: Design and methods. Beverly Hills.

Mahendra Sapkota Ph.D. (https://orcid.org/0000-00017854-6554) is a Visiting Faculty of Central Department of Rural Development, Tribhuvan University. He holds Ph.D. in Development Studies from a collaborative research engagement of Kathmandu University, Nepal and Zurich University, Switzerland. Currently, he is engaging in a postdoctoral study in Tibetan Studies at School of Ethnology and Sociology, Yunnan University, PR China.

Email: sapkota.mahendra27@gmail.com 